\title{
Propylene Epoxidation: High-Throughput Screening of Supported Metal Catalysts Combinatorially Prepared by Rapid Sol-Gel Method
}

\author{
Isik Onal • Derya Düzenli • Anusorn Seubsai • \\ Michael Kahn • Erol Seker · Selim Senkan
}

Published online: 22 December 2009

(C) Springer Science+Business Media, LLC 2009

\begin{abstract}
The gas phase oxidation of propylene using molecular oxygen was studied on a variety of supported metal catalysts. The most promising PO activity was obtained for $\mathrm{Cu}$ supported on high surface area $\mathrm{SiO}_{2}$ and the multimetallic systems exhibit synergistic effects that increased the desired PO yield by several folds for $\mathrm{Ag}$ promoted with $\mathrm{Cu}$ on $\mathrm{SiO}_{2}$ after screening a large number of catalysts by a high throughput testing technique.
\end{abstract}

Keywords Propylene $\cdot$ Epoxidation $\cdot$ Sol-gel $\cdot$

High-throughput

\section{Introduction}

Propylene oxide (PO) is an important raw material for the chemical industry. PO is produced commercially by the chlorohydrin and hydroperoxide processes. Because of the enviromental impacts of the chlorohydrin process, the most recently built plants are all using hydroperoxide process technologies. However, a disadvantage of hydroperoxide process is the production of co-products produced in a volume that is $\sim 3$ times larger than that of $\mathrm{PO}$; hence, the

I. Onal $(\bowtie)$

Middle East Technical University, Ankara 06531, Turkey

e-mail: ional@metu.edu.tr

D. Düzenli

General Directorate of Mineral Research and Exploration,

Ankara, Turkey

A. Seubsai $\cdot$ M. Kahn $\cdot$ S. Senkan

University of California Los Angeles, California, USA

E. Seker

Izmir Institute of Technology, Izmir 34430, Turkey economy of the process is primarily dominated by the market of the co-product [1].

The direct synthesis of $\mathrm{PO}$ by $\mathrm{O}_{2}$ or air in the gas phase has been under intense research due to environmentally friendly catalytic process and its relative simplicity. Among many catalyst formulation, $\mathrm{Au}$ and $\mathrm{Ag}$ on different support materials are the most widely investigated metals. Since Haruta et al. showed Au on titanium catalyst was very active for certain reactions, many researches based on $\mathrm{Au}$ supported on different support, e.g. TS-1, Ti-MCM-41, Ti-MCM-48 etc., have been performed to better understand the activity toward direct PO formation [2-9]. Despite high PO selectivity ( $\sim 99 \%)$ of the catalyst, propylene conversion is a very low; e.g. a few percent. Nevertheless, the addition of $\mathrm{H}_{2}$ as a co-reactant renders a requirement of extra treatment to separate the product which makes it less desirable for industrial application. Ag also is the most explored catalysts because of its success in EO synthesis reaction. Several supported and unsupported Ag catalysts modified with various promoters were tested to improve selectivity to $\mathrm{PO}$ at high propylene conversions [9-19]. The best modifier for $\mathrm{Ag}$ catalysts, e.g. for $\mathrm{Ag} / \mathrm{CO}_{3}$, were determined as $\mathrm{NaCl}$ which increase the $\mathrm{PO}$ selectivity to a maximum of $40 \%$ at $1-3 \%$ conversion. Similarly, $31.6 \%$ PO selectivity at $12.4 \%$ conversion and $33.4 \%$ PO selectivity at $18.6 \%$ conversion were obtained for unsupported $\mathrm{Ag}$ catalysts modified with $\mathrm{NaCl}$ [10-12]. In contrast, when $\mathrm{Ag}$ is loaded in titanium containing silicate support, $91.21 \%$ PO selectivity were obtained at $0.92 \%$ conversion $[13,14]$.

Most recently $\mathrm{Mo}$ and $\mathrm{Cu}$ were reported to be effective in the production of PO. $43.6 \%$ PO selectivity at $17.6 \%$ propylene conversion obtained over $\mathrm{Mo} / \mathrm{SiO}_{2}$ catalysts under a relatively higher pressure of $5 \mathrm{~atm}$. were determined due to the post-catalytic volume effect [20]. $\mathrm{Cu}$ has also been reported as an active catalyst in the direct production of $\mathrm{PO}$ 
without $\mathrm{H}_{2}$ although the initial yields $(0.12 \%)$ were much lower than those required for commercial interest [21-25]. Hexagonal mesoporous silicas (HMS) containing transition metals such as Ti- and Al-synthesized with sol-gel method showed $47.8 \%$ of propylene conversion and $30.6 \%$ of selectivity of PO. However deactivation of the catalysts during the reaction is very high and not suppressed completely by the addition of $\mathrm{H}_{2}$ [26].

The lack of a breakthrough in propylene epoxidation catalysis, in spite of world-wide efforts, clearly suggests the need to develop novel approaches for catalyst research and development. This fact, coupled with the abundance of catalytic materials that must be explored to discover new leads, e.g. binary, ternary and higher order combinations of metals as well as a large variety of support materials, call for the application of combinatorial or high throughput heterogeneous catalysis tools and methods. Senkan and coworkers made pioneering contributions to this field through the development of novel high-throughput catalyst preparation and screening tools [27-31]. In particular, they developed array channel micro-reactors to rapidly screen a large numbers of catalytic materials in parallel [27, 28]. Recently, they developed a high-throughput pulsed laser ablation (HT-PLA) system for the synthesis of uniformly sized single- and multi-metallic nanoparticles for catalytic applications [31].

In order to be able to synthesize catalysts in a much faster combinatorial fashion, a commercial synthesis apparatus was adapted to prepare catalysts with a sol-gel method in our laboratory. The synthesis apparatus was for highthroughput application where 24 catalysts can be simultaneously synthesized. The reactor block provides a reflux capability by the circulation of cold water. Magnetic stirring is also provided for each tube where a catalyst is synthesized. Reflux capability is an advantage during synthesis of the catalysts, such as silica and alumina that require high temperature conditions. Also, inert gas atmosphere conditions can be provided if required during catalyst synthesis.

In this study, a large number of catalysts were synthesized with sol-gel method and screened to determine active catalysts for propylene epoxidation reaction. In this respect, various metals were loaded into the various support materials by a single step sol-gel method and incipient wetness method to investigate the effect of metal loading and metalsupport interaction on the conversion and selectivity.

\section{Experimental}

\subsection{Catalyst Preparation}

All catalyst candidates supported on various support materials containing silica, alumina and titania were prepared combinatorially by using a single step sol-gel method in a magnetically stirred, constant temperature reactor block with 24 tubes and by incipient wetness method.

Silica supported catalysts were prepared with the following precursors; tetraethyl orthosilicate (TEOS) as silica source, ethanol (EtOH) as a solvent, deionized water, $1 \mathrm{M}$ of $\mathrm{HNO}_{3}, 0.5 \mathrm{M}$ of $\mathrm{NH}_{4} \mathrm{OH}$ and copper $(\mathrm{Cu})$, silver $(\mathrm{Ag})$ and manganase $(\mathrm{Mn})$ nitrate as a metal source $\left(\mathrm{Cu}\left(\mathrm{NO}_{3}\right)_{2}\right.$, $\mathrm{AgNO}_{3}$ and $\left.\mathrm{Mn}\left(\mathrm{NO}_{3}\right)_{2}\right)$. The corresponding molar ratio of TEOS:EtOH: $\mathrm{HNO}_{3}: \mathrm{H}_{2} \mathrm{O}: \mathrm{NH}_{4} \mathrm{OH}$ were 1:(10,20,30):1:13:0.5 and metal precursors were loaded in the range of from 0.5 to 20 weight ratio. First, TEOS, the corresponding amount of EtOH, $1 \mathrm{M}$ of $\mathrm{HNO}_{3}$, and water were mixed by stirring at room temperature and heated to $80^{\circ} \mathrm{C}$. Then, the metal precursor was added under vigorous stirring and reflux condition. Finally, $\mathrm{NH}_{4} \mathrm{OH}$ was added to the clear solution and stirred for few minutes more before gelling. The obtained gel was aged at room temperature, then dried at $120^{\circ} \mathrm{C}$ and calcined at $550{ }^{\circ} \mathrm{C}$ in air.

The precursors for alumina supported catalysts were aluminum isopropoxide (AIP), concentrated $\mathrm{HNO}_{3}$ and deionized water in the molar ratio of 1:0.195:(30,60,90) and the same weight ratios for the metal precursors was also used. The necessary amount of water was heated to $85^{\circ} \mathrm{C}$ and the corresponding amount of AIP was added to water at $85^{\circ} \mathrm{C}$ under vigorous stirring for one hour. To obtain clear solution, the necessary amount of concentrated $\mathrm{HNO}_{3}$ acid was added to the slurry and kept it stirred for $1 \mathrm{~h}$. The metal precursor was added to this solution and was kept stirred for additional $1 \mathrm{~h}$ and then the heater was switched off but the solution was kept stirred for one day. All the procedures were carried out under total reflux conditions. The clear solution was again heated to evaporate the solvent at low temperature without stirring until gel was obtained. The obtained gel was dried at $120{ }^{\circ} \mathrm{C}$ for overnight and calcined at $550{ }^{\circ} \mathrm{C}$ for a certain time.

The preparation method of supported $\mathrm{TiO}_{2}$ was as follows; the corresponding amount of tetrabutyl orthatitanate (TBOT) as a Ti source was added to EtOH with stirring at room temperature. The necessary amount of $\mathrm{HNO}_{3}$ acid was added to the above mixture. In the other tube the necessary amount of metal precursor was dissolved into the deionized water and added to the clear mixture of TBOT, EtOH and $\mathrm{HNO}_{3}$. The solution was kept stirred until the gel was obtained. The obtained gel was dried at $100{ }^{\circ} \mathrm{C}$, and calcined at various temperatures.

Meso-type silica $\left(\mathrm{m}-\mathrm{SiO}_{2}\right)$ was prepared according to the method given in the literature [26]. The basis was taken as $1 \mathrm{~g}$ of silica. The corresponding amount of dodecylamine (DDA) as a template, deionized water and the concentrated $\mathrm{HNO}_{3}$ were mixed in a tube and stirred for $1 \mathrm{~h}$. Then, the clear solution of TEOS and EtOH was added 
to this solution and continued to stir for $4 \mathrm{~h}$ at ambient temperature and pressure. The resulting mixture was aged for $20 \mathrm{~h}$ at room temperature. The obtained solid product was filtered, dried at $100{ }^{\circ} \mathrm{C}$ and calcined at $650{ }^{\circ} \mathrm{C}$ to remove template. Metal precursor was dissolved in water then other materials were added to this mixture in the same sequence for synthesizing metal containing catalysts. This procedure is similar to what is reported in the literature [26].

Mesosilicate containing 2 and 4 mol.\% of titanium was prepared as follows: the clear solution of TEOS in EtOH and TBOT in butanol (BA) were added to DDA, $\mathrm{H}_{2} \mathrm{O}$ and $\mathrm{HNO}_{3}$ mixture with vigorous stirring at ambient temperature for $4 \mathrm{~h}$ and aged for $20 \mathrm{~h}$. The resultant mixture was filtered, dried at $80{ }^{\circ} \mathrm{C}$ and calcined at $650{ }^{\circ} \mathrm{C}$.

In addition to the direct sol-gel method, $\alpha-\mathrm{Al}_{2} \mathrm{O}_{3}$ supported metal catalysts were prepared by use of incipient wetness method.

\subsection{Activity Tests}

Catalyst evaluations were performed using computer controlled array channel microreactor system described previously [27] in which up to 80 catalysts can be screened in parallel. In the array microreactors, reactant gases flow over the flat surfaces of catalyst powder which are individually isolated within reactor channels; the flow regime is similar to that of a monolithic reactor [30]. All experiments were performed under atmospheric pressure and at a gas hourly space velocity (GHSV) of $20,000 \mathrm{~h}^{-1}$, representing differential reactor conditions. Initial screening experiments were performed at temperatures of $300{ }^{\circ} \mathrm{C}$ using a feed gas composition of $20 \mathrm{vol} \% \mathrm{O}_{2}, 20 \mathrm{vol} \% \mathrm{C}_{3} \mathrm{H}_{6}$ and balance He. Reactor effluent gases were analyzed by withdrawing the products using a heated capillary sampling probe followed by on-line gas chromatography (Varian CP4900 Micro GC with thermal conductivity detector, Porapak Q $(10 \mathrm{~m})$ and Molecular sieve 13X (10 m) columns). The selectivity of PO is defined as the percent of carbon in PO among all the products.

\subsection{Characterization}

Powder X-ray diffraction (XRD) analysis was performed using Philips X'pert Pro XRD operated at $40 \mathrm{kV}$ and $45 \mathrm{~mA}$. The surface area of catalysts was obtained from Brunauer-Emmett-Teller (BET) plot and the pore size was obtained from Barrett-Joyner-Halenda (BJH) analysis by Micromeritics Gemini V and Micromeritics ASAP 2010 apparatus. X-ray photoelectron spectroscopy was performed to determine the oxidation state of the selected metals. The X-ray photoelectron spectra were obtained using $\mathrm{Mg} \mathrm{K} \alpha \quad(\mathrm{hv}=1253.6 \mathrm{eV}) \quad$ unmonochromatized radiation with SPECS spectrometer.

\section{Results and Discussion}

\subsection{Activity Test Results of Supported Ag Catalysts}

The propylene consumption rate and PO selectivity results as a function of $\mathrm{Ag}$ loading supported on five support materials $\left(\gamma-\mathrm{Al}_{2} \mathrm{O}_{3}, \alpha-\mathrm{Al}_{2} \mathrm{O}_{3}, \mathrm{TiO}_{2}, \mathrm{SiO}_{2}\right.$ and $\left.\mathrm{m}-\mathrm{SiO}_{2}\right)$ are shown in Fig. $1 \mathrm{a}$ and $\mathrm{b}$, respectively. As shown in the figures, propylene consumption rate increases with the metal loading and it reaches a maximum value of $367 \mu \mathrm{mol} / \mathrm{g}$ cat-min for $\gamma-\mathrm{Al}_{2} \mathrm{O}_{3}$ supported catalysts. The lowest propylene consumption rate was obtained over m$\mathrm{SiO}_{2}$ and $\mathrm{TiO}_{2}$. The Ag catalysts supported on silica synthesized with a DDA as a template and also Ag catalysts supported on commercial alumina did not improve propylene consumption rate but they improved the PO selectivity. Maximum PO production rate was $5.5 \mu \mathrm{mol} / \mathrm{g}$ cat-min over $20 \mathrm{wt} \% \mathrm{Ag}$ on commercial $\alpha-\mathrm{Al}_{2} \mathrm{O}_{3}$ (at $3.2 \%$ conversion and 4.2\% PO selectivity). The supported $\mathrm{Ag}$ catalysts in general mainly produced $\mathrm{CO}_{2}$. However, the maximum the maximum propionaldehyde plus acrolein $(\mathrm{PaL}+\mathrm{AC})$ selectivity as a major $\mathrm{C}_{3}$ product reached $30 \%$ over $\mathrm{Ag} / \mathrm{m}-\mathrm{SiO}_{2}$ and the maximum acetone (AT) selectivity as a second major $\mathrm{C}_{3}$ product was $5 \%$ over $\mathrm{Ag} / \gamma$ $\mathrm{Al}_{2} \mathrm{O}_{3}$.

According to the XRD results, a small peak belonging to $\mathrm{Ag}(111)$ was observed when $1 \mathrm{wt} \% \mathrm{Ag}$ was loaded into $\mathrm{SiO}_{2}$ synthesized by direct sol-gel method, and an increasing the $\mathrm{Ag}$ amount to $10 \mathrm{wt} \%$ caused an appreciable increase in the peak intensity. This trend was also confirmed by XPS analysis for high and low Ag loadings. The intensity of $\mathrm{Ag} 3 \mathrm{~d}_{5 / 2}$ peak is higher for $10 \% \mathrm{Ag} / \mathrm{SiO}_{2}$ than for $1 \% \mathrm{Ag} / \mathrm{SiO}_{2}$ catalyst and the $\mathrm{Ag}$ was metallic form regardless of Ag loading. We found that the $\mathrm{PO}$ production rate and propylene conversion rate increased with the metal amount for $\mathrm{Ag} / \alpha-\mathrm{Al}_{2} \mathrm{O}_{3}$ catalyst (Fig. 1a and b). It seems that the large $\mathrm{Ag}$ particles are desirable for PO production for $\alpha-\mathrm{Al}_{2} \mathrm{O}_{3}$. However, this may not be true for other support materials as can be seen in activity test results given in Fig. 1a and b.

\subsection{Supported $\mathrm{Cu}$ Catalysts}

Silica supports containing 2 and 4 mol.\% titanium were also synthesized in addition to the five supports used for $\mathrm{Ag}$ catalysts to investigate the catalytic activity of $\mathrm{Cu}$ containing catalysts. The propylene consumption rate and $\mathrm{PO}$ selectivity for various supports and $\mathrm{Cu}$ metal loading are given in Figs. 2 and 3. 
Fig. 1 a $\mathrm{C}_{3} \mathrm{H}_{6}$ consumption rate and (b) $\mathrm{PO}$ selectivity for supported Ag catalysts
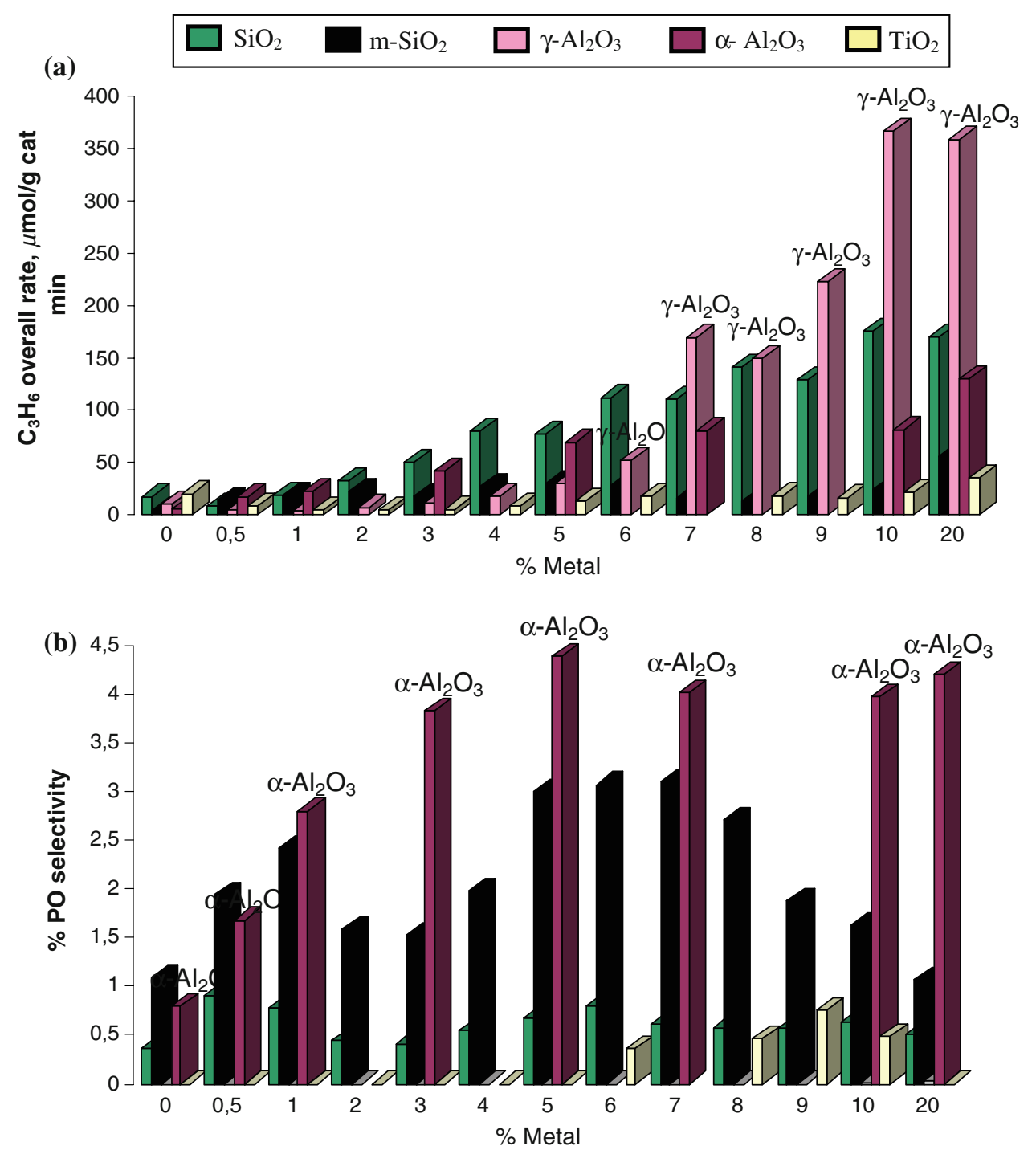

The maximum propylene consumption rate was obtained on $2 \% \mathrm{Cu} / \mathrm{TiO}_{2}$ as $552 \mu \mathrm{mol} / \mathrm{g}$ cat-min. However, it produced the lowest $\mathrm{C}_{3}$ epoxidation product selectivity (max. PaL + AC selectivity as $11.8 \%$ and AT selectivity as $2.2 \%$ ). Although $\gamma-\mathrm{Al}_{2} \mathrm{O}_{3}$ is the least effective support material in terms of $\mathrm{PO}$ selectivity, $\mathrm{C}_{3}$ product selectivities reached $35.8 \%$ for $\mathrm{PaL}+\mathrm{AC}$ and $8.4 \%$ for $\mathrm{AT}$ over for $2 \% \mathrm{Cu} / \gamma-\mathrm{Al}_{2} \mathrm{O}_{3}$ catalyst. Among the 7 support materials indicated in Figs. 2 and 3, silica materials are the most promising catalysts for PO synthesis. Selectivity toward PO $(10.7 \%)$ was the highest for $2 \% \mathrm{Cu} / \mathrm{m}-\mathrm{SiO}_{2}$ at $2 \%$ propylene conversion. At the same conversion value, the PO selectivity obtained over $\mathrm{SiO}_{2}$ is 5 times lower than m$\mathrm{SiO}_{2}$. For $\mathrm{m}-\mathrm{SiO}_{2}$, an increase in $\mathrm{Cu}$ loading from 1 to $3 \%$ results in a slight decrease in PO selectivity. However, a further increase causes a significant decrease in PO selectivity (3.4\% PO selectivity for $10 \mathrm{wt} \% \mathrm{Cu})$. Similarly, better PO selectivity and propylene conversion was observed over $\mathrm{SiO}_{2}$. For $\mathrm{SiO}_{2}$ and $\mathrm{m}-\mathrm{SiO}_{2}$ supported $\mathrm{Cu}$ catalysts, the major product is $\mathrm{PaL}+\mathrm{AC}(60-70 \%)$ almost at all metal loadings. AT selectivity is $9.5 \%$ for $\mathrm{SiO}_{2}$ but $1.8 \%$ for $\mathrm{m}-\mathrm{SiO}_{2}$ at low metal loading and it falls with an increase of loading.

To improve the activity of $\mathrm{m}-\mathrm{SiO}_{2}$ support material, 2 and $4 \mathrm{~mol} \%$ titanium was added into the structure in accordance with literature studies [26]. However an expected increase in the performance was not observed for titanium silicate support materials, neither propylene consumption rate nor selectivity to $\mathrm{PO}$ was improved by $\mathrm{Ti}$ addition.

In order to determine the oxidation state of $\mathrm{Cu}$ at high and low metal loadings, XPS analysis was performed on the fresh 0.5 and $9 \% \mathrm{Cu} / \mathrm{SiO}_{2}$ as shown in Fig. 4. The binding energy at 937.6 and $935.8 \mathrm{eV}$ indicates the presence of isolated-like ionic $\mathrm{Cu}^{+2}$ species for the catalyst with low metal loading. However, for $9 \% \mathrm{Cu} / \mathrm{SiO}_{2}$ 
Fig. $2 \mathrm{C}_{3} \mathrm{H}_{6}$ consumption rate of supported $\mathrm{Cu}$ catalysts $\mathrm{SiO}_{2}$, $\gamma-\mathrm{Al}_{2} \mathrm{O}_{3}, \alpha-\mathrm{Al}_{2} \mathrm{O}_{3} \mathrm{TiO}_{2}, \mathrm{~m}-\mathrm{SiO}_{2}$, $2 \% \mathrm{Ti}-\mathrm{Si}, 4 \% \mathrm{Ti}-\mathrm{Si}$

Fig. 3 PO selectivity of supported $\mathrm{Cu}$ catalysts $\mathrm{SiO}_{2}$, $\gamma-\mathrm{Al}_{2} \mathrm{O}_{3}, \alpha-\mathrm{Al}_{2} \mathrm{O}_{3} \mathrm{TiO}_{2}$, $\mathrm{m}-\mathrm{SiO}_{2}, 2 \% \mathrm{Ti}-\mathrm{Si}, 4 \% \mathrm{Ti}-\mathrm{Si}$
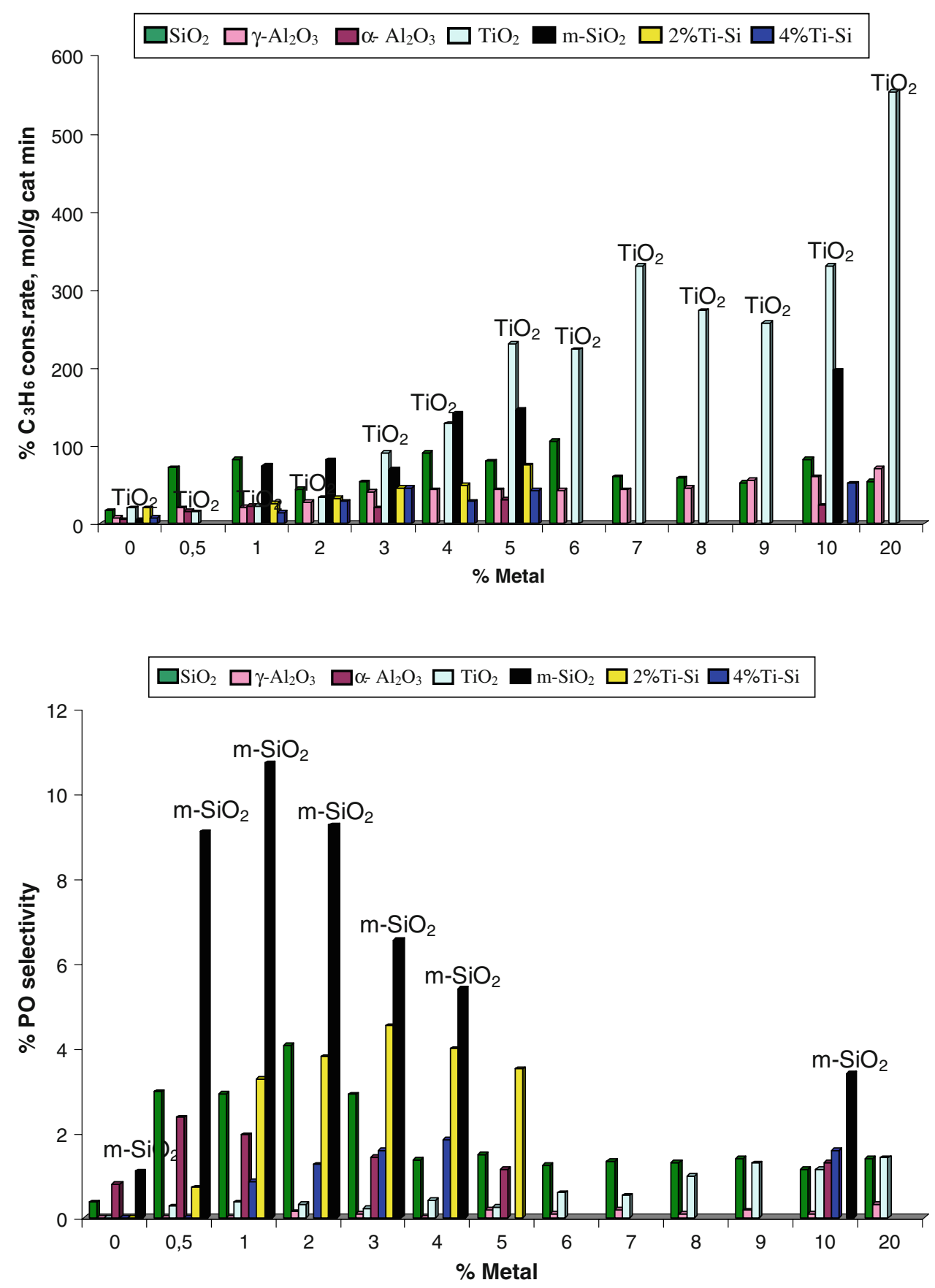

catalysts, the binding energy at $933.7 \mathrm{eV}$ is attributed to the existence of $\mathrm{Cu}^{2+}$ species in $\mathrm{CuO}$ form and the binding energy at 934.3 and $936.5 \mathrm{eV}$ indicates $\mathrm{Cu}$ existing in the isolated-like ionic form. This point seems to be controversial in the literature. For example, $\mathrm{Lu}$ and Vaughen state that metallic copper is an active state for propene epoxidation and $\mathrm{Cu}$ with high valence causes combustion reaction and acrolein production [21, 22]. In another study, Chu and co-workers state that copper in oxidized state $\left(\mathrm{Cu}^{\mathrm{I}}\right.$ or $\mathrm{Cu}^{\mathrm{II}}$ ) is responsible for epoxidation of $\mathrm{C}_{3} \mathrm{H}_{6}$ by $\mathrm{O}_{2}[23,24]$.

\subsection{Activity Test Results of Supported Mn Catalysts}

$\mathrm{Cu}$ and $\mathrm{Ag}$ were previously reported to be active towards PO synthesis from propylene and oxygen especially for promoted catalysts whereas $\mathrm{Mn}$ has not been investigated in detail. So, supported Mn catalysts were synthesized and tested in this study too. We found that Mn catalysts generally caused low propylene conversion $(<0.1 \%)$ and low PO selectivity $(<0.5 \%)$. Among the seven support materials, the best performance was obtained for $\mathrm{m}-\mathrm{SiO}_{2}(4.7 \%$ 


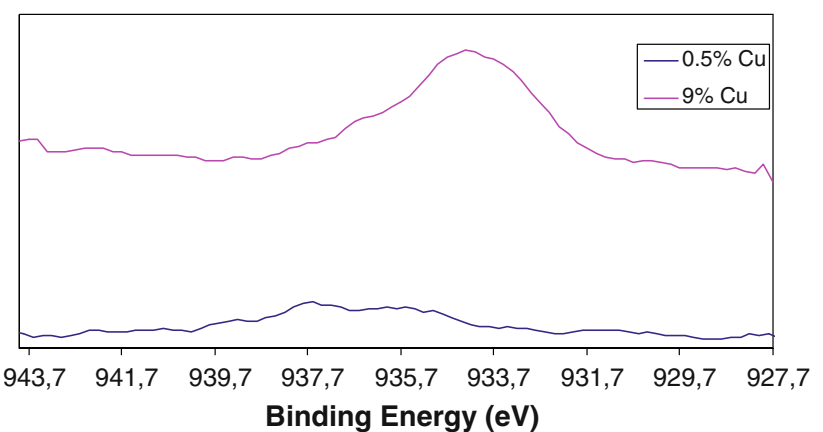

Fig. 4 XPS spectrum of 0.5 and $9 \% \mathrm{Cu} / \mathrm{SiO}_{2}$

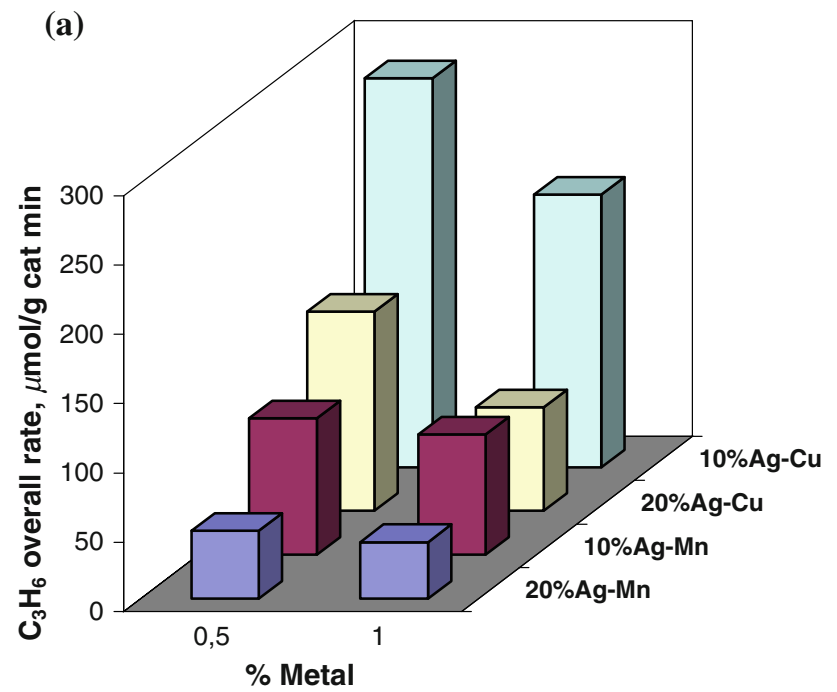

(b)

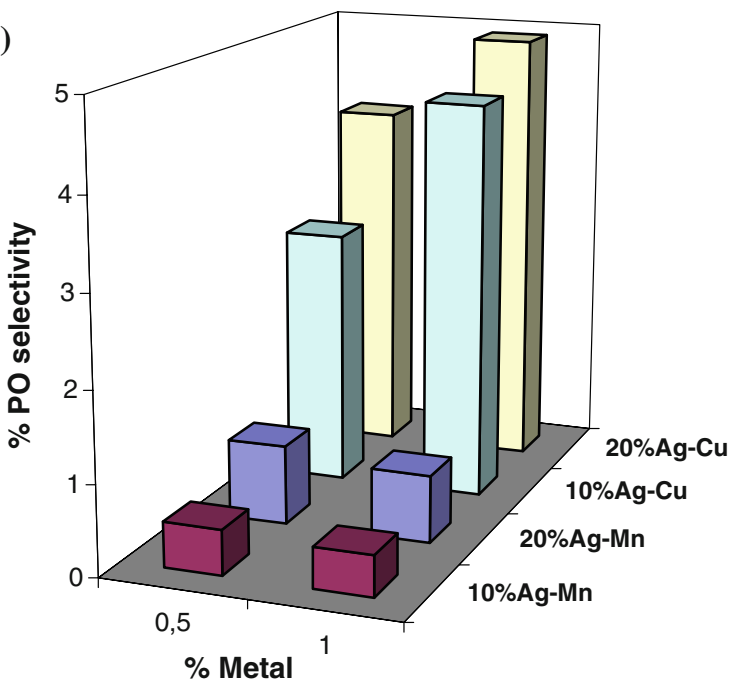

Fig. 5 Activity and selectivity of $\mathrm{Ag} \& \mathrm{Cu}$ and $\mathrm{Ag} \& \mathrm{Mn} / \mathrm{SiO}_{2}$ catalysts

PO selectivity at $0.2 \% \quad \mathrm{C}_{3} \mathrm{H}_{6}$ conversion). $\mathrm{TiO}_{2}$ catalyst provided the highest $\mathrm{C}_{3} \mathrm{H}_{6}$ conversion $(8.4 \%)$ despite the lower PO selectivity $(0.1 \%)$. When the results are investigated in terms of the other $\mathrm{C}_{3}$ products, selectivity to $\mathrm{PaL}+\mathrm{AC}$ are $45-60 \%$ and AT 2-20\% at low metal loadings for all supports except $\alpha$ - and $\gamma-\mathrm{Al}_{2} \mathrm{O}_{3}$. The products obtained for Mn supported on $\gamma$ - and $\alpha-\mathrm{Al}_{2} \mathrm{O}_{3}$ are almost completely $\mathrm{CO}_{2}$ (indicating complete combustion rather than partial oxidation so the results are not shown).

\subsection{Activity Test Results of Supported Bimetallic Catalysts}

A total of 10 and $20 \mathrm{wt} \% \mathrm{Ag}$ supported on $\mathrm{SiO}_{2}$ catalysts were promoted with low amounts $(0.5$ and $1 \mathrm{wt} \%)$ of $\mathrm{Cu}$ and $\mathrm{Mn}$ to improve the PO yield. The propylene consumption rate and $\mathrm{PO}$ selectivity were given in Fig. 5a and b. In the absence of $\mathrm{Cu}$ and $\mathrm{Mn}$, the propylene consumption rate and $\mathrm{PO}$ selectivity were $176 \mu \mathrm{mol} / \mathrm{g}$ cat-min and $0.6 \%$ for $10 \% \mathrm{Ag} / \mathrm{SiO}_{2}$ and $170 \mu \mathrm{mol} / \mathrm{g}$-cat min and $0.5 \%$ for $20 \% \mathrm{Ag} / \mathrm{SiO}_{2}$ respectively. It is of interest that, after addition of $\mathrm{Cu}$ at 0.5 and $1 \mathrm{wt} \%$ levels, both propylene consumption rate and $\mathrm{PO}$ selectivity increased significantly for $10 \% \mathrm{Ag} / \mathrm{SiO}_{2}$ catalyst. When $0.5 \% \mathrm{Cu}$ was added to the $10 \% \mathrm{Ag}, \mathrm{C}_{3} \mathrm{H}_{6}$ consumption rate and $\mathrm{PO}$ selectivity increased to $281 \mu \mathrm{mol} / \mathrm{g}$ cat-min and $2.9 \%$. Further addition of $\mathrm{Cu}(1 \%)$ increased consumption rate to $197 \mu \mathrm{mol} / \mathrm{g}$ cat-min and PO selectivity to $4.5 \%$. The consumption rate of propylene over $20 \% \mathrm{Ag}$ catalysts promoted with 0.5 and
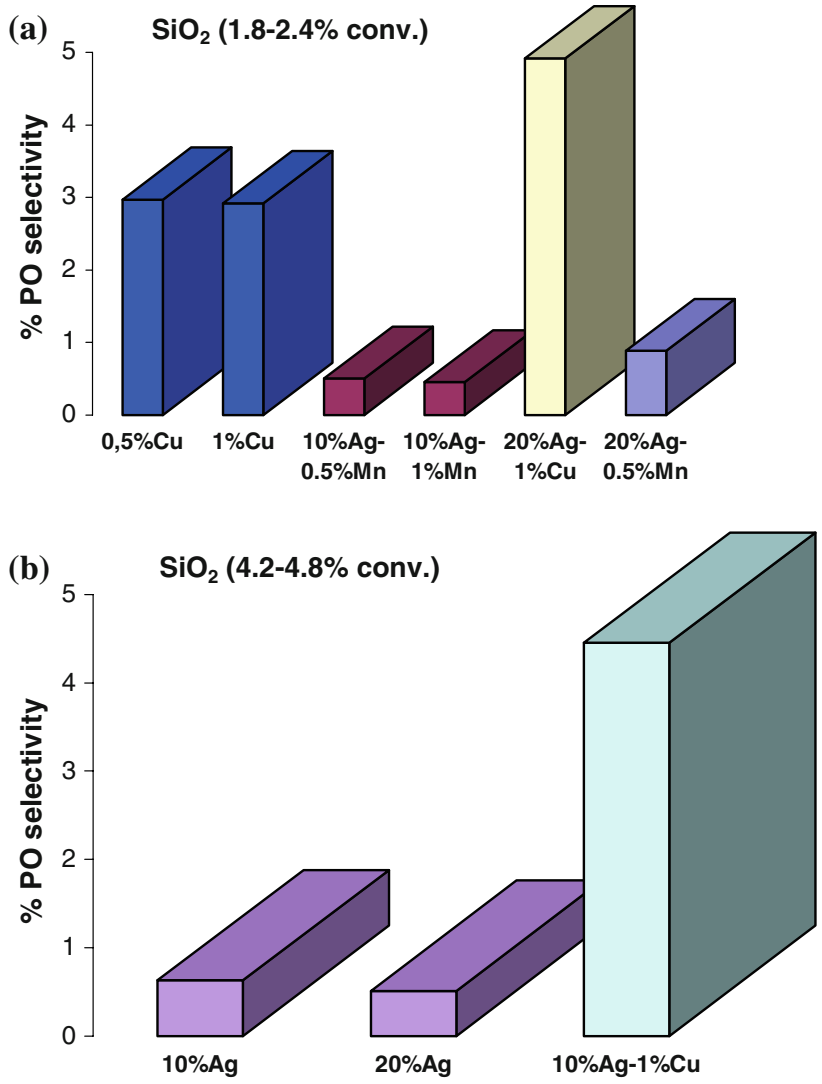

Fig. $6 \mathrm{PO}$ selectivity of $\mathrm{Ag} \& \mathrm{Cu}$ and $\mathrm{Ag} \& \mathrm{Mn} / \mathrm{SiO}_{2}$ catalysts at the same conversion values (a) $1.8-2.4 \%$ and (b) $4.2-4.8 \%$ conversion 

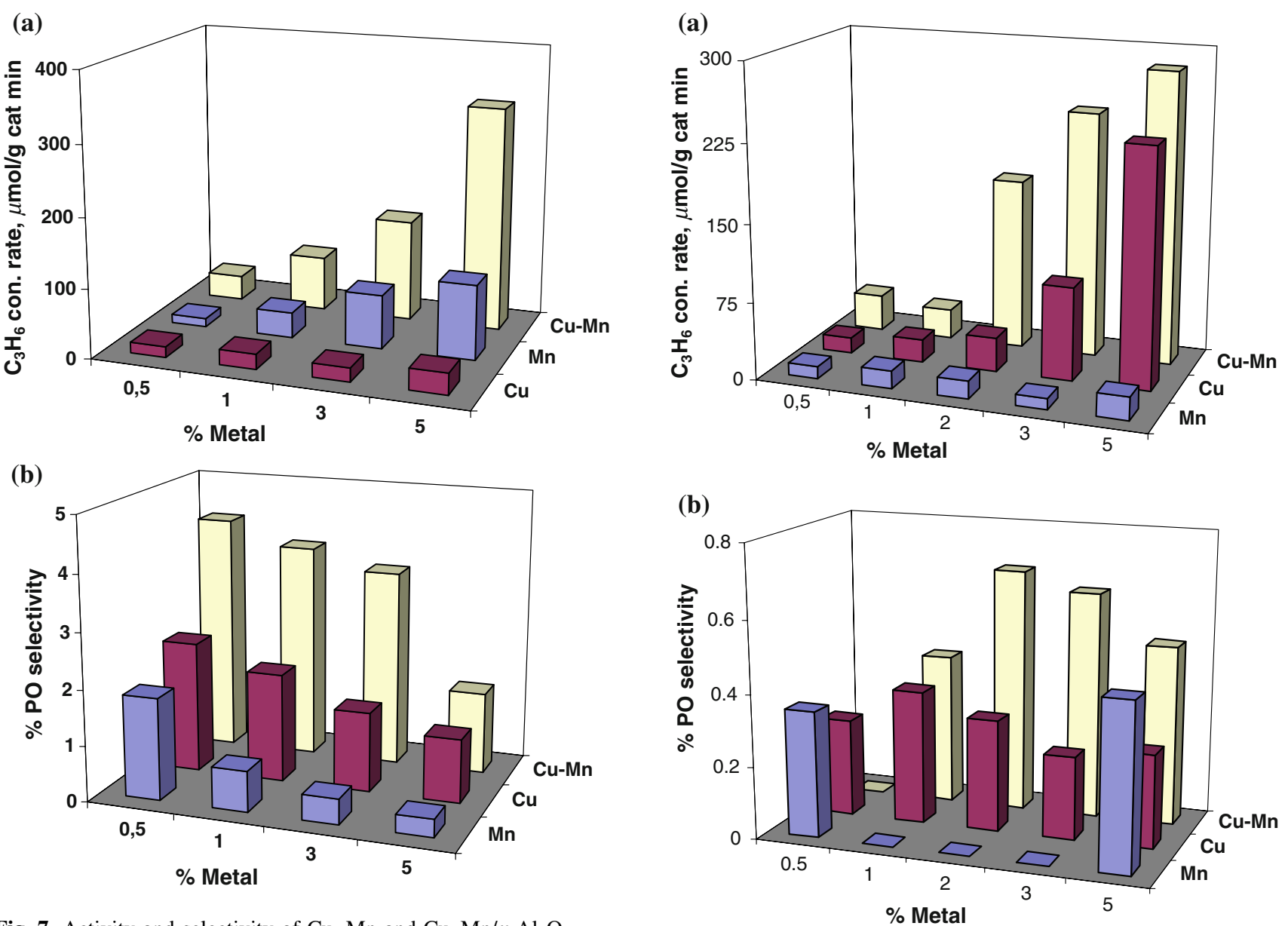

Fig. 7 Activity and selectivity of $\mathrm{Cu}, \mathrm{Mn}$ and $\mathrm{Cu}-\mathrm{Mn} / \alpha-\mathrm{Al}_{2} \mathrm{O}_{3}$

$1 \mathrm{wt} \% \mathrm{Cu}$ decreased from 176 to 144 and $75 \mu \mathrm{mol} / \mathrm{g}$ catmin respectively but it led to an improvement toward the PO selectivity by a factor of 7-10 as compared to an unpromoted $\mathrm{Ag}$ catalyst $(0.5 \%)$ and by a factor of $\sim 2$ as compared to single $\mathrm{Cu}$ catalyst at almost the same conversion levels. $10 \% \mathrm{Ag} / \mathrm{SiO}_{2}$ catalysts promoted with 0.5 and $1 \mathrm{wt} \% \mathrm{Mn}$ did not show better PO production rate despite a decrease in $\mathrm{C}_{3} \mathrm{H}_{6}$ conversion. Although slightly better PO selectivity were observed over the $0.5 \% \mathrm{Mn}$ $20 \% \mathrm{Ag} / \mathrm{SiO}_{2}$ and $1 \% \mathrm{Mn}-20 \% \mathrm{Ag} / \mathrm{SiO}_{2}$ catalysts, these catalysts showed remarkably low propylene conversion ( $\sim 45 \mu \mathrm{mol} / \mathrm{g}$ cat-min). A synergetic effect of $\mathrm{Ag}-\mathrm{Cu}$ catalysts is clearly illustrated on isoconversion-selectivity graphs as seen in Fig. 6a and b. When propylene conversions were between $1.8-2.4 \%$ (Fig. 6a) and 4.2-4.8\% (Fig. 6b), the highest selectivity toward PO was obtained for $20 \% \mathrm{Ag}-1 \% \mathrm{Cu}$ as $4.9 \%$ and for $10 \% \mathrm{Ag}-1 \% \mathrm{Cu}$ as $4.4 \%$.

$\mathrm{Cu}$ and $\mathrm{Mn}$ supported on $\mathrm{m}-\mathrm{SiO}_{2}, \alpha-\mathrm{Al}_{2} \mathrm{O}_{3}$ and $\mathrm{TiO}_{2}$ were also studied. $\alpha-\mathrm{Al}_{2} \mathrm{O}_{3}$ and $\mathrm{TiO}_{2}$ supported $\mathrm{Cu}-\mathrm{Mn}$ showed better catalytic performance than their corresponding single metal catalysts. The synergy between $\mathrm{Cu}$ and $\mathrm{Mn}$ on these support materials improves $\mathrm{PO}$ yields by several folds. For $\alpha-\mathrm{Al}_{2} \mathrm{O}_{3}$ supported bimetallic and

Fig. 8 Activity and selectivity of $\mathrm{Cu}, \mathrm{Mn}$ and $\mathrm{Cu}-\mathrm{Mn} / \mathrm{TiO}_{2}$ catalysts

unimetalic catalysts, $\mathrm{Cu}-\mathrm{Mn}$ combination gave a better $\mathrm{PO}$ selectivity and a propylene consumption rate than their unimetallic counterparts (Fig. 7a and b). At similar low and high conversion levels, $\mathrm{PO}$ selectivity is approximately 5 times higher as compared to single metal catalysts. $\mathrm{TiO}_{2}$ supported catalyst group again showed a better activity and a PO selectivity for the bimetallic systems (Fig. 8a and b). Generally, at $0.7-0.9 \%$ and $3.1-5.8 \%$ iso-conversion values the bimetallic systems gave slightly better catalytic performance than unimetallic systems. However, at high conversions, $\mathrm{PO}$ production rate of $\mathrm{Cu} / \mathrm{TiO}_{2}$ catalyst was higher than the bimetallic system. $\mathrm{Cu}-\mathrm{Mn} / \mathrm{m}-\mathrm{SiO}_{2}$ catalysts did not enhance the catalytic activity and the PO selectivity as compared with $\mathrm{Cu} / \mathrm{m}-\mathrm{SiO}_{2}$ catalyst. This observation is contrary to what is observed for $\mathrm{Cu}-\mathrm{Mn} / \alpha-\mathrm{Al}_{2} \mathrm{O}_{3}$ and $\mathrm{Cu}-$ $\mathrm{Mn} / \mathrm{TiO}_{2}$ catalysts systems.

\section{Conclusions}

High-throughput sol-gel catalyst synthesis and also highthroughput screening methods were used to investigate the 
effects of metal loading, support-metal and metal-metal interactions for the direct synthesis of PO from propylene and oxygen. Our results show that the most appropriate support material is silica synthesized with the DDA template and $\mathrm{Cu}$ is the most promising metal for direct epoxidation of propylene to $\mathrm{PO}$ at low $\mathrm{Cu}$ loadings. Ionic species of $\mathrm{Cu}^{2+}$ and large metallic $\mathrm{Ag}$ particles seem to be responsible for $\mathrm{PO}$ gas phase synthesis. The results also show that multimetallic systems can exhibit synergistic effects, improving the $\mathrm{PO}$ yield by several folds especially for $\mathrm{Ag}$ promoted with $\mathrm{Cu}$ on $\mathrm{SiO}_{2}$ synthesized without template and $\mathrm{Cu}$ and $\mathrm{Mn}$ bimetallic system supported on $\alpha-\mathrm{Al}_{2} \mathrm{O}_{3}$. These new leads reported in this manuscript must be studied in more detail in order to optimize both the catalyst preparation process and the reactor operating conditions (e.g. residence time, temperature, inlet gas stoichiometry etc.) to fully explore the potential of $\mathrm{Cu}$ on silica, $\mathrm{Ag}-\mathrm{Cu}$ and $\mathrm{Cu}-\mathrm{Mn}$ bimetallic systems in direct $\mathrm{PO}$ synthesis. These results illustrate the importance of exploring multimetallic systems and the useful role that high-throughput methods may play in catalyst research and development.

Acknowledgments This research was supported in part by TÜBITTAK (The Scientific and Technological Research Council of Turkey) Project No:104M134. High throughput testing facilities at UCLA were provided by Prof. Selim Senkan. The authors also extend their special thanks to General Directorate of Mineral Research and Exploration (MTA) for providing laboratory facilities.

\section{References}

1. Nijhuis TA, Makkee M, Moulijn JA, Weckhuysen BM (2006) Ind Eng Chem Res 45:3447

2. Qi C, Akita T, Okumura M, Haruta M (2001) Appl Catal A Gen 218:81

3. Hayashi T, Tanaka K, Haruta M (1998) J Catal 178:566 (3)

4. Sinha AK, Seelan S, Tsubota S, Haruta M (2004) Top Catal 29:95

5. Sacaliuc E, Beale AM, Weckhuysen BM, Nijhuis TA (2007) J Catal 248:235
6. Chowdhury B, Suarez JJB, Date M, Tsubota S, Haruta M (2006) Angew Chem Int Ed 45:412

7. Stangland EE, Stavens KB, Andres RP, Delgass WN (2000) J Catal 191:332-347

8. Lu J, Zhang X, Suarez JJB, Bando KK, Fujitane T, Oyama ST (2007) J Catal 250:350

9. Zwijnenburg A, Makkee M, Mouljin JA (2004) Appl Catal 270:49

10. Lu G, Zuo X (1999) Catal Lett 58:67

11. Lu J, Luo M, Lei H, Li C (2002) Appl Catal A Gen 237:11

12. Lu J, Suarez JJB, Haruta M, Oyama ST (2006) Appl Catal A Gen 302:283

13. Wang R, Guo X, Wang X, Hao J (2003) Catal Lett 90:57

14. Wang R, Hao J, Guo X, Wang X, Liu X (2004) Stud Surf Sci Catal 154:2632

15. Fotopoulos AP, Triantafyllidis KS (2007) Catal Today 127:148

16. Palermo A, Husain A, Tikhov MS, Lambert RM (2002) J Catal 207:331

17. Takahashi A, Hamakawa N, Nakamura I, Fujitani T (2005) Appl Catal A Gen 294:34

18. Jin G, Lu G, Guo Y, Guo Y, Wang J, Liu X (2004) Catal Today 93-95:173

19. Jin G, Lu G, Guo Y, Guo Y, Wang J, Kong W, Liu X (2005) J Mol Catal A Chem 232:165

20. Song Z, Mimura N, Bravo-Suarez JJ, Akita T, Tsubota S, Oyama ST (2007) Appl Catal A Gen 316:142

21. Lu J, Luo M, Lei H, Bao X, Li C (2002) J Catal 211:552

22. Vaughan OPH, Kyriakou G, Macleod N, Tikhov M, Lambert RM (2005) J Catal 236:401

23. Chu H, Yang L, Zhang Q, Wang Y (2006) J Catal 241:225

24. Wang Y, Chu H, Zhu W, Zhang Q (2008) Catal Today 131:496

25. Torres D, Lopez N, Illas F, Lambert RM (2007) Angew Chem Int Ed 46:2055

26. Liu Y, Murata K, Inaba M, Mimura N (2006) Appl Catal A Gen 309:91

27. Senkan S (2001) Angew Chem Int Ed 40:312

28. Senkan S, Ozturk S (1999) Angew Chem Int Ed 38:791

29. Senkan S, Krantz K, Ozturk S, Zengin V, Onal I (1999) Angew Chem Int Ed 38:2794

30. Duan S, Kahn M, Senkan S (2007) Comb Chem High Through Screen 10:111

31. Senkan S, Kahn M, Duan S, Ly A, Liedholm C (2006) Catal Today 117:291 